Section Editor

John J. Millichap, MD

\title{
Teaching NeuroImages: \\ Red ear syndrome
}

Dheeraj Kalladka, MRCP Maxine Paul, FRCPath Alok Tyagi, FRCP

Correspondence to Dr. Kalladka:

dheeraj.kalladka@nhs.net
Download teaching slides: Neurology.org

\section{Figure Red pinna and punch biopsy}
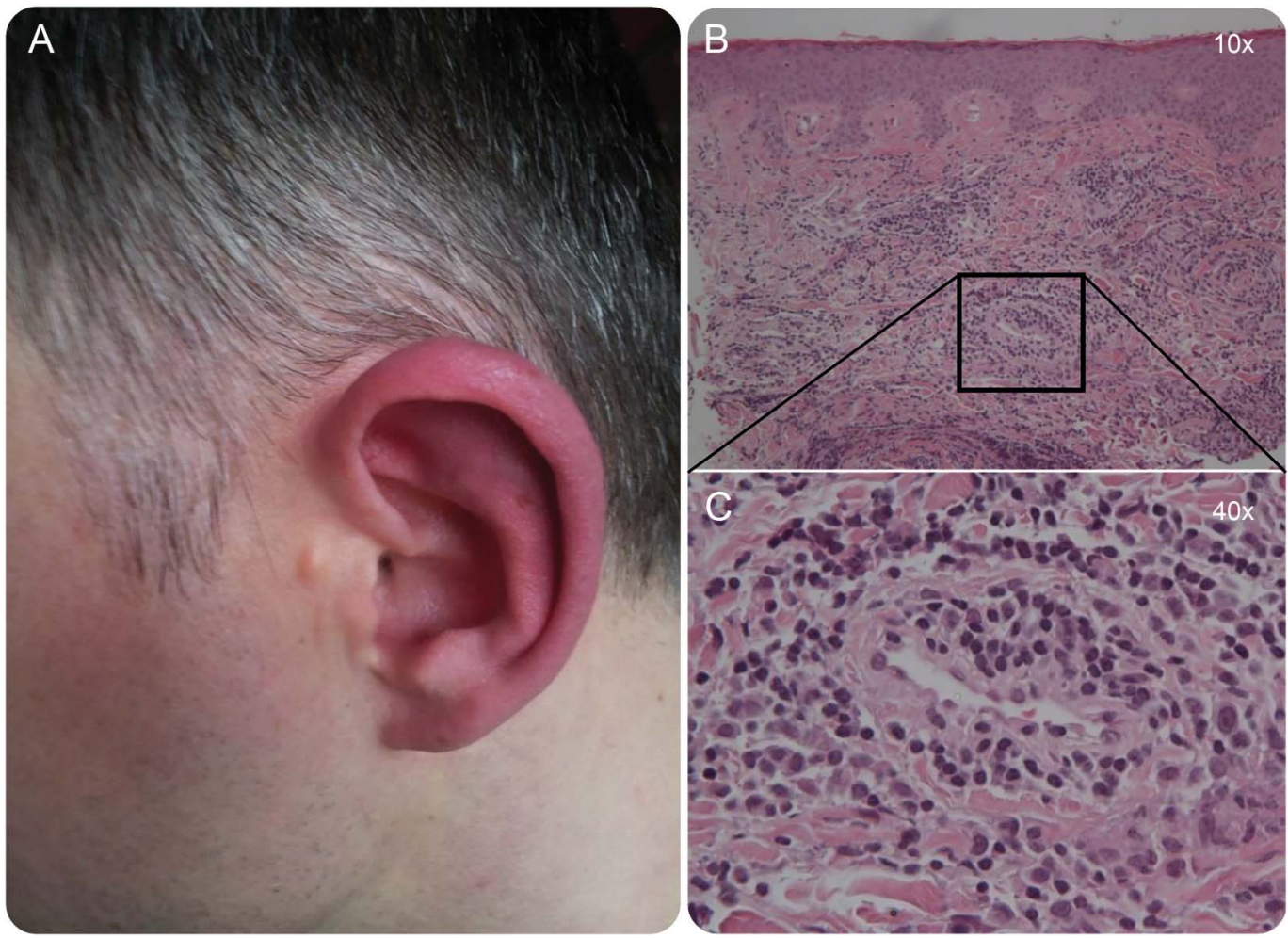

An inflamed left pinna (A). Punch biopsy shows a nonspecific dermal (10 $\times$ magnification) (B) and perivascular $(40 \times$ magnification) (C) inflammation. Hematoxylin and eosin stain.

A 41-year-old man presented with a 3-year history of unilateral pulsatile headaches associated with nausea, vomiting, photophobia, and 1 to 2 episodes per day of red, burning, itchy, and painful left pinna, lasting 4 hours, triggered by touch, increased temperature, and sun exposure (figure). The migraine headaches and the red pinna were temporally associated. His brother has migraines only. Examination was normal. MRI of the head and cervical spine including angiogram was unremarkable. Blood and CSF analyses were normal. Ear symptoms were worse with steroids. Betablockers and amitriptyline were unhelpful. Gabapentin has shown some benefit in reducing the frequency of attacks. This condition is called red ear syndrome and its pathophysiology is unclear. Secondary causes such as thalamic syndrome, temporomandibular joint dysfunction, carotid body adenoma, upper cervical spine lesions including Chiari I malformations, and vertebral artery compression at C3 need to be ruled out and migraine prophylaxis considered in migrainerelated attacks. ${ }^{1,2}$

\section{AUTHOR CONTRIBUTIONS}

Dr. Kalladka: patient review, drafted manuscript, and revisions. Dr. Paul: biopsy reporting and review of manuscript. Dr. Tyagi: consultant in charge and critical review of manuscript.

From the Departments of Neurology (D.K., A.T.) and Pathology (M.P.), Institute of Neurological Sciences, Queen Elizabeth University Hospital, Glasgow, UK

Go to Neurology.org for full disclosures. Funding information and disclosures deemed relevant by the authors, if any, are provided at the end of the article. 
STUDY FUNDING

No targeted funding reported.

DISCLOSURE

The authors report no disclosures relevant to the manuscript. Go to

Neurology.org for full disclosures.
REFERENCES

1. Lance JW. The red ear syndrome. Neurology 1996;47: 617-620.

2. Lambru G, Miller S, Matharu MS. The red ear syndrome. J Headache Pain 2013;14:83. 


\title{
Neurology
}

\author{
Teaching NeuroImages: Red ear syndrome \\ Dheeraj Kalladka, Maxine Paul and Alok Tyagi \\ Neurology 2016;86; e177-e178 \\ DOI 10.1212/WNL.0000000000002588
}

This information is current as of April 18, 2016

Updated Information \&
Services
Supplementary Material
References
Subspecialty Collections
Permissions \& Licensing
Reprints

Updated Information \&

Supplementary Material

\section{References}

Subspecialty Collections

Reprints including high resolution figures, can be found at: http://n.neurology.org/content/86/16/e177.full

Supplementary material can be found at: http://n.neurology.org/content/suppl/2016/04/16/WNL.0000000000002 588.DC1

This article cites 2 articles, 1 of which you can access for free at: http://n.neurology.org/content/86/16/e177.full\#ref-list-1

This article, along with others on similar topics, appears in the following collection(s):

All Clinical Neurology

http://n.neurology.org/cgi/collection/all_clinical_neurology Migraine

http://n.neurology.org/cgi/collection/migraine

Information about reproducing this article in parts (figures,tables) or in its entirety can be found online at:

http://www.neurology.org/about/about_the_journal\#permissions

Information about ordering reprints can be found online:

http://n.neurology.org/subscribers/advertise

Neurology ${ }^{\circledR}$ is the official journal of the American Academy of Neurology. Published continuously since 1951, it is now a weekly with 48 issues per year. Copyright () 2016 American Academy of Neurology. All rights reserved. Print ISSN: 0028-3878. Online ISSN: 1526-632X.

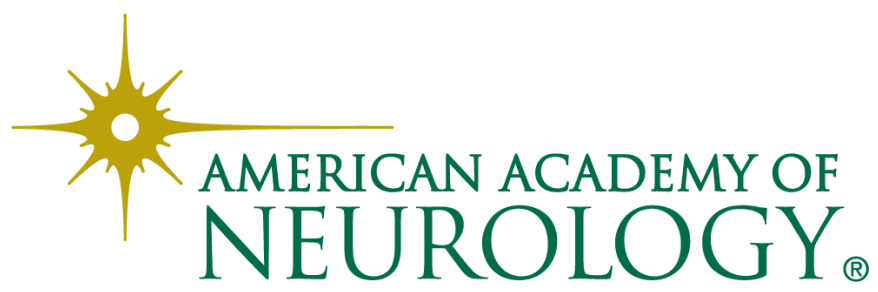

